Ioana Jieanu

Faculty od Arts

University of Ljubljana

University of Craiova

University of Ploiești (UPG)

jieanui@ff.uni-lj.si
UDK 811.135.1'373.23:81'282.8(450+460)

DOI: $10.4312 /$ vestnik.7.71-85

\title{
ONOMASTIC INTERFERENCES IN THE LANGUAGE OF MIGRATION
}

\section{INTRODUCTION}

Migration is currently one of the most discussed social phenomena, since it has a very high impact on countries from which emigration occurs as well as on immigrant receiving countries. It has been estimated that there are between 125 and 130 million immigrants around the world, taking into account only first generation immigrants and not their descendants, born in the destination countries (Aguinaga Roustan 1998: 34). This figure does not include migration waves from countries involved in armed conflicts. According to OECD ${ }^{1}$ (World Migration in Figures. A joint contribution by UN-DESA and the OECD to the United Nations High-Level Dialogue on Migration and Development 2013), in 2013², the number of international migrants was 232 million, having increased by 77 million since 1990 .

\begin{tabular}{|l|l|l|l|}
\hline 1990 & 2000 & 2010 & 2013 \\
\hline 154.2 & 174.5 & 220.7 & 231.5 \\
\hline
\end{tabular}

Table 1. Evolution of international migration according to data published by OECD.

Since December $1989^{3}$, many Romanian people have chosen to emigrate, in search of a better life. If at first Romanian migration was directed, particularly, towards Germany and France, after the year 2000 most Romanian people chose to immigrate to Spain and Italy. In recent years Romanian emigrants have chosen Great Britain and the Nordic countries as their most popular host countries.

In this work, we shall focus on the analysis of onomastic interferences which appear within contacts between the Romanian language and the Italian / Spanish languages, within

\footnotetext{
1 The Organisation for Economic Co-operation and Development

2 The most recent information about international migration which we were able to find dates from 2013.

3 In 1989, the Communist regime in Romania, which had been installed by Nicolae Ceaușescu, collapsed after the Romanian revolution.
} 
the context of Romanian migration to Italy and Spain. It has been estimated that there are now over two million Romanian people ${ }^{4}$ in these two countries. In fact, in 2013 a total of 1.071.324 Romanian people had been registered in Italy, whereas in the same year the number of Romanians in Spain reached 769.6085.

\section{LITERATURE OVERVIEW}

Richard D. Alford (1988: 69) observed that naming systems fulfil two main functions: differentiation and classification. Whereas the first function extracts the individual from the social environment and makes him unique: "the bestowal of a name on a child indicates either that the child is a legitimate member of the society (e.g. citizenship) and / or that the child's parents are publicly claiming parenthood." (Alford 1988: 125), the second function is implemented through the last name, which places the individual within a family, a society, and a culture.

Generally, people from all societies bear between one and four first names (Kiviniemi 2006: 14). In Romania, each individual has, in most cases, two first names. This trend has also been preserved in the naming of children born abroad, even if this is not customary in the host society.

In the case of bilingual speakers, proper names undergo various different types of transformations, depending on the contextual character of the manifestation of meanings, i.e. "the relation between the proper name and the denoted object being temporary, and dependent on the verbal and situational context" (Tomescu 1998: 1).

Studies that have dealt with naming in the case of immigrants (Berry 2007, Gerards and Hans 2006, Lieberson 2000, Finch 2008) have promoted the idea that immigrants, for their new-borns, choose first names from the host society, and there are only very rare cases in which the children receive names that are specific to the society of origin, this fact representing evidence of assimilation by the host society. According to Gerards and Hans 2006: 4 "It is voluntary and desired identification with the host society on the part of immigrants", so that choosing a name specific to the host society demonstrates the immigrants' desire to integrate, or the identity desired by the parents for their children: "a child's first name signifies the identity the parents want for their children". Janet Finch (2008: 712) agreed that people's names form a part of their social identity and "it follows that a name is both a legal identifier of the individual but also potentially part of social identity". In the case of mixed marriages there is a tendency to choose names from the host society (Berry 1997), considering that names derived from the mother tongue lose their importance, and are replaced by their equivalents from the language of the host country (Lieberson 2000).

$4 \quad$ Legal and illegal immigrants.

5 The most recent official data published by INE (the Spanish National Institute of Statistics) date from 2013. 


\section{RESEARCH AIMS}

In this work, an attempt has been made to analyse Romanian-Spanish and Romanian-Italian onomastic interferences at the level of Romanian naming within the migration communities. Two perspectives have been investigated:

a. analysis of interferences which emerge within communication, in case of the proper names of Romanian people who emigrated to Spain and Italy;

b. classification of the proper names of new-borns within Romanian families who have settled in these countries.

In the analysis of the first names of Romanian immigrants in Spain, and Italy we have focussed on two aspects:

a. the assignment of first names to new-borns;

b. the use of Romanian people's names in communication.

The present work will try to answer the following questions: What kind of name do Romanian parents from the migration communities choose for their children? What factors influence the choice of name? How does Spanish or Italian naming practice influence name choice? Are the names used in communication considered as identity forms?

The idea of the present study started from contacts with Romanian immigrants in Spain and Italy, which gave us the opportunity to discover many interesting facts and nuances about this phenomenon, as well as about the consequences of Romanian migration in these two countries. We noticed that Romanian names are adapted to the Spanish and Italian phonetic systems, respectively. During preliminary research it was also observed that Romanian people in Spain and Italy prefer to give their children, if born in either of these two countries, Spanish or Italian first names, thus contributing to their future integration within the societies in which they have chosen to raise their children. Another important aspect of our work was concerned with an analysis of the last names of Romanian people living abroad and, in particular, of children born in Spain and Italy.

The functional and semantic particularities of proper names: "denomination through identification and individualization" and "denotative mobility and freedom which determines the contextual character of the manifestation of meaning." (Tomescu 1998: 1) were used in the author's approach.

\section{METHODOLOGY}

During our research several obstacles were encountered. Firstly, we did not have any access to official information, since such information is considered to be confidential and personal. Our requests for such information which were addressed to the Consulate General of 
Romania in Trieste and the Consulate General of Romania in Torino, Italy, the Consulate General of Romania in Castellón de la Plana, Spain, all the Orthodox Churches in Italy and Spain, the Civil Registry Office of Sector I City Hall, Bucharest, and the Romanian Language Institute, Bucharest, were denied.

A considerable amount of data for this study was, however, obtained by directly interviewing Romanian people in Spain and Italy, as well as through discussions with Romanian officials in Spain (the Consulate of Romania in Castellón) and in Italy (the Consulate of Romania in Trieste), as well as with representatives of the Orthodox Church in the two countries, Romanian Associations, and the Romanian Language Institute. A lot of useful information was provided by some teachers of $\mathrm{LCCR}^{6}$ from Spain and Italy. These interviews were recorded, and material consisting of 78 hours of discussions was assembled. The recorded material was used for another investigation (Jieanu 2015), but some of the subjects' remarks about onomastics were analysed in this work, too.

In order to obtain more information about the names of Romanian people living in Italy and Spain, the author distributed questionnaires (on e-mail, Facebook - individuals or in groups). Knowing the purpose of our research, very few people were willing to answer our questions. A total of 28 questionnaires were, in fact, filled in, but we also received 58 answers to direct questions posted within the following Facebook groups: Rumañol, Romanian Community in Spain, as well as on the following pages: Romanians abroad, the Association of Romanians in Valencia, Romania from Barcelona, The Romanian from Spain, Romanians in Spain, Rumanos en la Rioja, Romanian Spain, Radio Romanian Spain and Romanians from Andalucia Spain.

\section{RESULTS}

\subsection{First and last names of Romanian children born in Spain}

\subsubsection{First names of newly-born children}

Among the most frequent names of newly-born children, the Civil Status Registry of Castellón includes Arabic names such as Fátima, Mohamed, Mariam and traditional Romanian names: Nicoleta, Adrian, Georgiana, Alexandru, and Alex.

According to data supplied by INE (http://www.ine.es/) in 2013, names which are common to both the Spanish and Romanian language can be identified among the 20 most frequently used names of boys and girls, but not specific Romanian first names, as in the case of the Arabic names: Daniel, David, Gabriel, Sebastian, Adrian, Maria, Paula, Sofia, Lucia, Laura, Sara, Claudia, Ana, Elena, and Carmen. In the province of Castellón, the

6 The organization: Romanian Language, Culture and Civilization. LCCR courses are organized by ILR (the Romanian Language Institute) and are available to Romanian children studying in schools located in Spain and Italy. 
specific Romanian names: Alex, Victor and Andreea can be found among the 20 most frequently used names for new-borns.

In Spain, the Romanian first names which appear most frequently in the Spanish Registries are: Ioan, Vasile, Gheorghe, Ion, Constantin, Nicolae, Daniel, Florin, Marian, Mihai, Adrian, Maria, Elena, Mariana, Mihaela, Ana Maria, Daniela, Ana, Nicoleta, Ioana, and Cristina, whereas the following Romanian last names are found there: Pop, Popa, Radu, Moldovan, Dumitru, Stan, Constantin, Stoica, Gheorghe, Mihai, Vasile, Popescu, Matei, Șerban, Ștefan, Ilie, Marin, Rus, Rusu, and Ciobanu.

By analysing the replies which were obtained using the questionnaire that was uploaded onto the internet, both individual questionnaires and those posted in groups (What names do the children born in Spain / Italy bear?), in conjunction with the lists of students enrolled at $\mathrm{LCCR}^{7}$ and the Registry for the entry of children baptized at St. Nicholas Church, Castellón, four customary ways of naming new-borns were observed:

a) The registered children bear Romanian names: Nicolae, Daniel, George Ion, Andreea, Raluca, Monica Ioana, Elena, Denisa, Cristina, Daniela, and Cătălina. In the lists of children enrolled in LCCR courses, we have also found children with both Romanian first names: Andrei Mihai Gabriel, Florei Alexandru Ionuț, and Mihăilă Robert Ștefan. Alfonso Perez, the president of the Romanian Association in Castellón, explains the use of names of Romanian origin as a form of "remembering the native country and Romanian traditions".

b) Some of the children baptized in Orthodox churches in Spain bear both a Romanian first name and a Spanish first name: Sara Dorina, Nicoleta Dolores, Alexandra Pilar, Antonio George, Ángel Catalin, Elisa-Maria, Ainoa-Sorina, Raul Andrei, Beatriz Paula, Mario Antonie, Daniel Nicolas, Diana Alejandra, Cristian Matias, Cornel Mario, and Larisa Beatriz.

c) When having their children baptized, some parents opt for one or two Spanish first names: Alicidora, Anabel, Andrés, Coral, David Nicolás, Diego, Eduardo, Erik Josep (a Catalan first name), Javier, Juan, Julian, Maria Isabel, Mario, Mireya, Nicolas, Roberto or Gorka, Itziar, Arkaitz, Irati, Mikel (a Basque first name), Jose Alberto, Julian David, Lucia Fernarda, Angel Rivera, Nicolas Andres, Fabian David, and Jean Carlos.

d) Some Romanian parents give their children first names which are common to both the Spanish and the Romanian language: Ana-Maria, Carmen, Daniel, David, Eduard, Elena, Laura, Lucia, Maria, Paula, and Sebastian.

e) Some children are given internationally recognized first names (this occurs only infrequently in the case of the naming of Romanian children in Spain): Emily, Sean, Patrick.

7 Some of the teachers of the LCCR - Romanian Language, Culture and Civilization - employees of the Romanian Language Institute have sent lists with the names of Romanian children enrolled in these courses.

8 "Recordar el país y las tradiciones rumanas" (Alfonso Perez). 
In case of mixed marriages, frequently, children receive only Spanish names, e.g. Agapie Mejia Lucia Fernarda, and Muñoz Ticuță Raul Andres.

\subsubsection{Last names}

The last names of Romanian children born in Spain are not modified except in the case of children from mixed marriages. Neither the man nor the woman changes their name when they get married. If the husband's name is Ion Popescu, and his wife's name is Maria Simion, they both retain the same name after marriage. If they have children, they will assume the last name of the father, in compliance with Romanian legislation. If the parents have both obtained Spanish nationality prior to having offspring, then any children born to them will bear both last names, the first being the last name of the father, and the second being the last name of the mother, e.g. Adrian Popescu Simion / Adriana Popescu Simion, in compliance with Spanish legislation, even if, in the meantime, the mother has given up her maiden name. We end up with names such as: Raul Alin Petre-Ciobanu. Petre-Ciobanu is the last name of the child, made up of the last name of the father (Petre) and the last name of the mother (Ciobanu), even if, at the time of birth, the mother had assumed last name Petre from her husband after marriage. Examples of names of children born in Spain are: Cioară Flores Cristian Matias, Covaciu Cârpaci Narcis Emanuel, Drăgan Stoica Fabian David, Drăgan Stoica Cornel Mario, and Agapie Mejia Lucia Fernarda.

In the case of mixed marriages, the child will bear the first last name of the father and the first last name of the mother. For instance, if the child's mother is of Spanish origin and her name is Feliciana Rodriguez Bosch, and if the father is Romanian and his name is Ion Popescu, then child will receive a name such as: Florian Popescu Rodriguez or Diana Popescu Rodriguez. If, on the other hand, the father is of Spanish origin, e.g. Jorge Molina Fuster, and the mother is Romanian, e.g. Maria Simion, then child will bear a name such as Florina Molina Simion or Diana Molina Simion. Thus the children of couples consisting of a Spanish man and a Romanian woman, or vice versa, will get a last name made up of a Spanish name and a Romanian one (Alejandro Gabriel Lopez Gliga).

Some Romanian women who married Spanish men, and wished to take the name of their husbands, have succeeded in doing this after declaring their marriage in Romania or within the Romanian Institutions located in Spain (i.e. the embassy or consulate).

\subsection{First and last names of Romanian children born in Italy}

According to $\operatorname{ISTAT}^{9}$ (http://www.istat.it/en), in 2011 a total of 106.000 children were born, in Italy, to foreign parents or mixed couples, i.e. with an Italian father or mother, the other partner being of foreign origin. Of these, 14.408 were children with Romanian parents, and 4.076 children with one Romanian parent.

9 The Italian National Institute of Statistics. 
The names most commonly given by Romanians to their children in Italy are: David, Matteo, Alexandru, Alessandro, Gabriel, Davide, Alessia, Alessia Maria, Giulia, Sara, Sofia, and Ștefania. As can be seen, among the twelve most frequently selected names of Romanian children born in Italy, only two are specific Romanian names, i.e. Alexandru and Ştefania. Four of the names are common in the Romanian language, as well as in the Italian language, i.e. David, Gabriel, Sara, and Sofia, whereas the rest of the names are specific Italian names.

\subsubsection{First names of new-born children}

The Italian language has a strong influence on the names which parents select for their newborn children. In order for their sons and daughters to feel accepted by the host society, Romanians living in Italy most frequently give their children an Italian first name, or register their children with first names which are common to the Italian and Romanian languages. In comparison with the situation with regard to the naming of new-born children in Spain, in Italy there are very few Romanians who chose names specific to the Romanian language.

Sometimes, the second first name is Romanian, this being due to the influence exercised by the orthodox religion. Many of those interviewed admitted that, at the advice of a priest, they decided to add a Romanian first name to the Italian one chosen at birth. The classification of children's names born in Spain also applies to children born in Italy:

a) Registered children were given the following Romanian names: Alexandru, AmaliaMaria, Andra, Andrei, Andreia Paula ${ }^{10}$, Andrei-Cristian, Cristian, Damian, Daniel, Daniil, Daria-Gabriela, Iustin-Andrei, Maria-Bianca, Marian, Marian-Constantin, Mihaela, Mihai, Sofia-Maria, Ștefan, Sebastian, Victor, Victoria, Andreea Gabriela, Georgiana, Lavinia, Daria Andreea, Livia, Radu Ștefan, Alex, Adriana Teodora, Alexandra Elena, Daria Ioana, Mădălin, Ionuț, Teodor, Robert Andrei, Maria, Mihai Eugen, Raluca, Larisa Gabriela, Narcis Cornel, Roxana, Cătălin, Cristian, Luca, Răzvan Darius, Diana Alexandra, Gabriela Anamaria, Mihai Petre, Mirela, Costi Valentin, Florentin, Alin Ovidiu, Florin Dragoș, Elena Laura, Andrei Cristian, Bianca Elena, Denis Valentin, Laura Maria, Adina Ecaterina, Adrian Grigore, Darius Alexandru, and Alexandra Maria.

b) Children who bear an Italian first name and a Romanian first name: Axel-Andrei, Carla-Maria, Francesco-Ioan, Georgia Gabriela, Jessica-Elena, Massimo-Andrei, S,tefan Matias, Giulia Maria, AlessiaMaria, Francesca Maria, Mario Gabriel, Iosif Fabrizzio, Nicoletta Roxana, Bianca Natallia, Paul Frederico, Frederica Maria, Mattia Andrei, Nicoletta Anamaria, Alessia Maria, Alessio Ionut, Rebeca Maria, and Maria Maddalena.

c) Some Romanian parents gave their children an Italian first name: Alessia, Alessio, Anna, Cataleya, Celeste, Dalida, Daniele, Danielle, Davide, Davide-Leon, Davyde,

10 Because Andrea is an Italian masculine name, the Italian authorities have prohibited the use of this name for girls. Because of this, the subject interviewed by us chose to spell her name Andreia instead of Andreea. 
Debora, Eduardo, Frederico, Gabrielle, Gaia, Gennaro, Giorgia, Giovanni, Giulia, Jessica, Matias Ralf, Matteo, Mattia, Melissa, Milena, Nicola-Edoardo, Nicolo, Raffaella, Raoul, Serena, Tommasso, Valerio, Francesco, Danielle Matteo, Nicola, Alessandro, Isabel, Chiara, Giuseppe, Leon, Gabriele, and Giulio Davide.

d) Other Romanian parents gave their children names which are common to both the Italian and the Romanian language, e.g. Alexia, Ana, David, Dennis, Elena, Emanuela, Laura, Lorena, Luca, Sofia, Veronica, and Virginia.

e) Yet other Romanian parents chose internationally recognized names for their children, e.g. Sophie, Alice, Edward, Jasmine, Ryana, Yasmine, Ahmed, Jessica, Rony, and Jasmina.

\subsubsection{Last names}

The last names of Romanian children born in Italy do not differ from the Romanian ones, since the Italian legislation requires that newly-born children bear the last name of the father. Therefore, only if the child's father is Italian and the mother is Romanian will the child shall bear an Italian last name.

Even though Italian children only receive one first name, many Romanian people still have their new-born children baptized with two first names, as is customary in Romania.

\subsection{Reasons for the choice of names}

There are quite a lot of reasons behind the choice of names. Immigrant parents choose certain names for their children because they like them, because of the way they sound, because of their significance, because they are innovative, rare, international, because they are used or pronounced in the same way in both languages (the language of the host country and the language of origin of the immigrant), in order to emphasize the relationship between the name and the country in which the child was born, and in order to fit the last name (Endter 2011: 58). Other reasons can be added, which have an influence on naming choices: literature, films, politics, stars (the popularity of artists, politicians, and athletes), models of other children's names, and a reason which is specific to Romanian people: naming children after a godparent or godparents.

To the question in the questionnaire: Which were the reasons for which they chose the names of their children?, the 28 respondents gave multiple answers: because they liked the name 20 , for its significance 2 , for its brevity 1 , because it is a rare name 0 , because it is an internationally recognized name 4, because the name is used both in Romania and in Spain / Italy respectively 12 , because it emphasizes the relationship with the country in which the child was born 18, in order to match the last name 2 , because of literary, political, artistic, and sports models 16 , for other reasons (e.g. when recommended by a priest, so that the child bears the name of a godparent or other relative) 14 . 


\section{DISCUSSION}

During the field research which was carried out in Spain and Italy, it was noticed that Romanian-Spanish and Romanian-Italian linguistic interference manifests itself also at the level of onomastics. In fact Romanian people from the Iberian Peninsula are called by Spanish people using names which are phonetically or even morphologically adapted to Spanish proper names, and many Romanians from the investigated area introduce themselves using a Spanish name. Our observations were reinforced by the priest of Saint Nicholas Church in Castellón, who told us, during an interview, that new-born children of Romanian descent who are baptized in Romanian churches located in Spain bear two names, one of which is Romanian, and the other Spanish. The results obtained during the research in Italy were similar to those obtained in in Spain. Romanian people from Italy, as well as those from Spain, introduce themselves using italianized names, and have their children baptized with Italian names.

This combination of names, i.e. a Romanian name and a Spanish / Italian name, is explained by the desire of Romanians to integrate within Spanish or Italian society, together with their longing for their own country and recognition of their origins (Perez $)^{11}$. In most cases, the Spanish / Italian name occurs in first place, which means that it is the name which is used in everyday communication. The second first name, the Romanian one, is motivated by the wish of the child's parents, "the desire to remember Romania"; it can also be the name of a godparent or of a family member, or is added to the Spanish name after birth, as is sometimes suggested by consular clerks, or is a response to the advice given by priests.

Currently, in Italy, at birth children receive a single first name, and take the last name of their father, in most cases, but also the last name of the mother (in the southern part of Italy). In accordance with Romanian tradition, Romanian children born in Italy, receive two first names. In most cases, one first name is of Italian origin, and the other is Romanian. In Spain, the same as in Romania, new-borns are registered with two first names and two last names (the last name of the father and the last name of the mother). The same as in the case of children born in Italy, whose parents choose to give them a Spanish name and a Romanian name, and, more often than not, adopt the Spanish method of forming the last name. Thus, Romanian children born in Spain have, in general, four names: two last names and two first names.

Based on the results of the field research carried out in Spain and Italy, and an interpretation of the filled-in questionnaires, it was noticed that Romanian people choose Spanish or Italian names for their children, their decision being motivated by a desire to integrate within the society in which they live. They also frequently choose a second first name of Romanian origin, usually the name of a saint, under the influence of their relatives or when recommended by a priest.

11 "Hay familias rumanas que ponen a sus hijos nombres españoles, como una forma de integración en las costumbres españolas". 


\subsection{Adaptation of Romanian names in Spanish}

Regarding the names of Romanian people used in communication in the Spanish language, two major tendencies were observed: firstly, the names of Romanian people are modified or spanishized, and secondly, last names are used instead of first names.

The exchange of Romanian names with similar Spanish names is often encountered. Some Romanian people voluntarily introduce themselves using the Spanish alternative of their names, so that other people can more easily remember them, and simultaneously so that the fact that they are immigrants is not emphasized: Ion and Ioana are replaced by Juan and Juana, Nicolae by Nicolás, and Alexandru by Alejandro.

Masculine Romanian names rarely receive the desinence - $o$, which is specific to Spanish names. Thus, some people who are called Valentin or Adrian introduce themselves with Valentino or Adriano.

The spanishization of Romanian names is frequently caused by the inability of Spaniards to correctly pronounce Romanian names. These transformations, which occur at the phonetic level, are determined by the absence from the Spanish phonetic system of the sounds corresponding to the following letters or groups of letters: $\breve{a}, \hat{a}, \hat{\imath}, s\}, t, v, g e, g i, c e$, and $c i$. Thus, a person who bears the name Laurențiu is called Laurentiu and a girl who bears the name Cătălina, Catalina.

Additionally, since Romanian people introduce themselves, for the first time, using the order: last name, first name, they are called by this last name: Nita is in fact Niță Alexan$d r u$, one of our respondents.

In the use of Romanian names by the Spanish, two phonetic accidents occur: betacism and prosthesis. Betacism is a "phonetic modification which consists in the confusion of $b$ with $v$, especially in the initial position" (Bidu-Vrânceanu et al. 2005: 86). This phenomenon is frequently encountered in the Spanish language. In speech, almost in all cases, the names Viorica, Viorel, Victor, Vasile, Vlad are pronounced Biorica, Biorel, Bictor, Basile, Blad.

Prosthesis is a "phonetic accident which consists in adding a non-etymological sound at the beginning of a word in order to ease its pronunciation", "adding a vowel at the beginning of a word" (Bidu-Vrânceanu et al. 2005: 417). In the Spanish language it is encountered in the case of words which start with the sound $s$ followed by a consonant. The sound $e$ is added in front of them. Prosthesis is encountered in the pronunciation of the Romanian names Ştefan, Ştefania, and Stela which become Estefan, Estafania and Estela.

\subsection{Adaptation of Romanian names in Italian}

In communication in the Italian language, Romanian names are adapted in the same way as in communication in the Spanish language: Italian translations of names are sometimes used (Ion - Giovanni), the names are pronounced according to the Italian phonetic system (David - Davíd, Mirela - Mirella), or the names receive Italian suffixes (Marian-Mariano, Eduard-Eduardo). 
Names of Boys ${ }^{12}$

\begin{tabular}{|l|l|l|}
\hline Romanian Name & Italian equivalent & Spanish equivalent \\
\hline Adrian & Adriano & Adrian \\
\hline Alex & Alessandro & Alex \\
\hline Alexandru & Alessandro & Alejandro \\
\hline Andrei & Andrea & Andrei \\
\hline Aurelian & Aureliano & Aureliano \\
\hline Bogdan & & Voldan \\
\hline Cătălin & Catalin & Catalin \\
\hline Constantin & Constantino /Tino & Constantino \\
\hline Damian & Damiano & \\
\hline Dani & Danielle & \\
\hline David & David & Davíd \\
\hline Florin & Floriano & Florin \\
\hline George / Gheorghe & Georgio & Jorge \\
\hline Ilie & Elia & \\
\hline lon & Gepetto & Juan \\
\hline lonuț & Giovanni / Geovanni / Gianni & lonut \\
\hline Irinel & Irinelle & \\
\hline lulian & Giuliano & Julian \\
\hline Lucian & Luciano & Lusian \\
\hline Marian & Mariano / Mario & Marian \\
\hline Petre / Patrik & Patrizzio & Pedro \\
\hline Robert & Roberto & Sebastian / Sebi \\
\hline Sebastian & Sebastiano & Bstefan \\
\hline Ștefan & Stefano & Teo \\
\hline Teodor & Victorio / Vitorio \\
\hline Victor & & \\
\hline & & \\
\hline
\end{tabular}

12 The names given in the tables were obtained from the questionnaire which was uploaded onto Facebook (see Appendix 1). 


\section{Names of Girls}

\begin{tabular}{|c|c|c|}
\hline Romanian Names & Italian equivalent & Spanish equivalent \\
\hline Adela & Adele & \\
\hline Alexadra & Alessandra & Alexandra \\
\hline Camelia & Camila & Camelia \\
\hline Cătălina & Catalina & Catalina \\
\hline Cerasela & Cerasella & \\
\hline Constanța & Constanța & Constanta \\
\hline Daniela & Daniele & Daniela \\
\hline Doina & Doi & \\
\hline Elena & Elena & Elena \\
\hline Fabiana & Fabiana & Fabiana \\
\hline Fănica & Fanni / Stefania & \\
\hline Gabriela & Gabri & \\
\hline Geanina & Giovana / Giannina & \\
\hline Georgeta & Georgia & Jorgeta (Horheta) \\
\hline Geta & Georgia & \\
\hline Gianina & Nina & \\
\hline loana & Giovanna & Juana \\
\hline Irina & Irina & Irina \\
\hline Iuliana & Georgia & \\
\hline Lenuța & Elena & \\
\hline Lucia & Lucía & Lusia \\
\hline Marinela & Marinella / Mirella & \\
\hline Mădălina & Madalina / Mada & Madalina \\
\hline Mihaela & Michaela / Micaela / Miki & Mihaela / Miaela \\
\hline Mioara & Mia & Mioara \\
\hline Mirela & Mirella & Mireya \\
\hline Nicoleta & Nicoleta Nicoletta & Nicoleta \\
\hline Petronela / Petro & Petra & Petronela \\
\hline Roxana & Rossana & \\
\hline Victoria & Vittoria & Bitoria \\
\hline
\end{tabular}

\section{CONCLUSIONS}

Onomastic borrowings are frequent: Romanians prefer to name their new-borns with a Romanian and a Spanish or Italian name, or just Spanish or Italian names. The names of 
Romanians from Spain and Italy, used in communication, are adapted to the Spanish and Italian phonetic systems, respectively, or translations into these two languages are used.

Bearing Romanian last names, Romanian children from Spain and Italy continue to belong, at least through their last name, to Romanian society, whereas the Italian and Spanish first names which they have suggest their integration or desire to integrate within the host society. The combination of an Italian first name and a Romanian last name demonstrates, once again, the dual identity of Romanian people within migration communities located in Spain and Italy. On the one hand to a considerable extent they do not belong to Romanian society, but they also do not belong fully to the host society. They have, in fact, created for themselves a new identity, and also given it a new name, in two variants: rumañols and rotalians (Jieanu 2012: 168).

\section{APPENDIX 1 - QUESTIONNAIRE UPLOADED ON FACEBOOK}

Hi! I intend to write an article about the names of Romanian people living abroad and I'd like to address a few questions. If you want, you can answer, if you find my post disturbing, I shall erase it.

1. How do the Italians / Spanish pronounce your names?

2. If you have children or you know people who have had children in Italy /Spain, what name have you chosen or they have chosen for them.

Thank you!

\section{Acknowledgments}

This work was supported by the strategic grant POSDRU/159/1.5/S/133255, Project ID 133255 (2014), co-financed by the European Social Fund within the Sectorial Operational Program Human Resources Development 2007-2013.

\section{REFERENCES}

AGUINAGA ROUSTAN, Josune (1999) Ciudadano o inmigrante. El proceso de integración en la sociedad española, in Tezanos J.F..Tendencias en Desigualdad y Exclusión Social. Madrid: Editorial Sistema.

PEREZ, A. El fenómeno de la inmigración. Nombres árabes y rumanos arrasan en el Registro Civil, September 9 2015. http:/www.elperiodicomediterraneo.com/noticias/ temadia/nombres-arabes-y-rumanos-arrasan-en-registro-civil_31338.html.

ALFORD, Richard D (1988) Naming and Identity: A cross-cultural study of personal naming practices. New Haven: Human Relations Area Files Press. 
ENDTER, Annekatrin (2011) Living Names, Naming Lives. On the naming practices of Germans living in Finland, A socio-onomastic study. September 18 2015. https:// jyx.jyu.fi/dspace/bitstream/handle/123456789/36726/URN\%3aNBN\%3afi\%3ajyu-2011092811464.pdf?sequence=1.

BERRY, John W. (2007) Acculturation Strategies and Adaptation.

BORNSTEIN, Marc H./Kirby DEATER-DECKARD/Jennifer E. LANSFORD (2009) Immigrant families in contemporary society. p. 69-82. New York: Guildford Publications.

BIDU-VRĂNCEANU, A., CĂLĂRAŞU, C., IONESCU-RUXĂNDOIU, L., MANCAŞ, M., PANĂ DINDELEGAN, G. (2005) Dicționar de ştiințe ale limbii, Bucureşti: Nemira.

FINCH, Janet (2008) Naming Names. Kinship, Individuality and Personal Names. Sociology 42 p. 709-723.

GERHARDS, Jürgen/Hans SILKE (2006) Zur Erklärung der Assimilation von Migranten an die Einwanderungsgesellschaft am Beispiel der Vergabe von Vornamen. Discussion Papers of DIW Berlin 583. Berlin: DIW.

JIEANU, Ioana (2012) Interferențe lingvistice româno-spaniole, Iași: Lumen.

JIEANU, Ioana (2015) Interferențe lexicale și onomastice în limbajul migrației, Timișoara: Editura de Vest.

KIVINIEMI, Eero (2006) Suomalaisten etunimet. Helsinki: Suomalaisen Kirjallisuuden Seura.

LIEBERSON, Stanley (2000) A Matter of Taste: How Names, Fashions and Culture Change. New Haven: Yale University Press.

TOMESCU, Domniţa (1998) Gramatica numelor proprii în limba română, Bucureşti: All Educational.

World Migration in Figures. A joint contribution by UN-DESA and the OECD to the United

Nations High-Level Dialogue on Migration and Development. 3-4 October 2013.

September 1 2015. http://www.oecd.org/els/mig/World-Migration-in-Figures.pdf Instituto Nacional de Estadística. May 4 2015. http://www.ine.es/.

Italian National Institute of Statistics. May 4 2015. http:/www.istat.it/en/.

\section{FACEBOOK GROUPS}

Rumañol. October 10 2013. https://www.facebook.com/groups/106802239343519/.

Noi doua si o umbrela. October 102013 .https://www.facebook.com/groups/gaabrielaritok/.

Romaniinstrainatate.https://www.facebook.com/pages/Romani-in-strainatate/428828277205858?fref=ts. October 102013.

Asociatia Romanilor Valencia. October 10 2013. https://www.facebook.com/arova?fref=ts.

Romania Din Barcelona. October 10 2013. https:/www.facebook.com/romaniadin.barcelona?fref $=$ ts 
Românul. October 10 2013. https://www.facebook.com/romanul?fref=ts.

Romani in Spania. October 10 2013. https://www.facebook.com/groups/romanispania/?fref $=$ ts.

Rumanos en la Rioja. October 10 2013. https://www.facebook.com/rumanos.enlarioja?fre$\mathrm{f}=\mathrm{ts}$.

Spania Romaneasca. October 10 2013. https://www.facebook.com/SpaniaRomaneasca?fref $=$ ts.

Radio Românul. October 10 2013. https://www.facebook.com/radioromanul?fref=ts.

Romanii din Andalucia Spania. October 10 2013. https://www.facebook.com/romaniidinandalucia.spania?fref $=$ ts.

Spania Românească. October 10 2013. http://forum.spaniaromaneasca.com/index.php.

\section{POVZETEK}

\section{Onomastične interference v jeziku migracij}

Pri dvojezičnih govorcih prihaja $v$ rabi lastnih imen do raznih sprememb. Te spremembe so povezane s kontekstualnim značajem, ki se izraža glede na pomen, t. j. začasno povezavo med lastnim imenom in obravnavanim predmetom, odvisno od govornega in situacijskega konteksta. V trenutni ekonomski migraciji Romunov v Španijo in Italijo so se romunska imena pod vplivom španske in italijanske onomastike spremenila. Namen tega dela je dvoje: preučiti interferenco, ki se pojavlja v lastnih imenih v komunikaciji romunskih izseljencev v Španiji in Italiji ter določiti klasifikacijo novonastalih lastnih imen v romunskih družinah, ki so se ustalile v teh dveh državah.

Ključne besede: jezikoslovna interferenca, onomastika, prilagoditev, rumañol, rotalian

\section{ABSTRACT}

\section{Onomastic Interferences in the Language of Migration}

In case of bilingual speakers, proper names undergo different transformations, depending on the contextual character of a manifestation of meanings, "the relationship between the proper name and the denoted object being temporary, dependent on the verbal and situational context" (Tomescu 1998: 1). Within the scope of the current economic migration of Romanians to Spain and Italy, the names of Romanian people have undergone various modifications under the influence of Spanish and Italian onomastics. In the present work, the performance of two main tasks is described: an analysis of the interferences which emerge within communication, in case of the proper names of Romanian people who have emigrated to Spain and Italy; and classification of the proper names of new-born children within Romanian families that have settled in these countries.

Key words: linguistic interference, onomastics, adaptation, rumañol, rotalian 